\title{
At 100 years of Gaceta Médica de México resumption
}

Martha Eugenia Rodríguez-Pérez, ${ }^{*}$ Carlos Andrés Rodríguez-Toledo ${ }^{1}$ and Eduardo Iván Cruz-Gaytáň ${ }^{1}$ Faculty of Medicine, Department of History and Philosophy of Medicine; ${ }^{2}$ Faculty of Philosophy and Literature. Universidad Nacional Autónoma de México, Mexico City, Mexico

\begin{abstract}
Gaceta Médica de México, official journal of the National Academy of Medicine of Mexico, began its circulation on September 15,1864 , and continues to be positioned as the oldest medical periodical publication. However, its publication was temporarily interrupted. The present study analyzes the interruption suffered by Gaceta in 1916, its resumption in 1919, and the causes that originated that discontinuity. The consequences of the so-called Mexican revolution and the enthusiasm and commitiment of the academy and its editors to continue working for the progress of national medicine are discussed.

KEY WORDS: Gaceta Médica de México. National Academy of Medicine of Mexico. Periodical publication.
\end{abstract}

\section{Introduction}

Since its origin in 1864, Gaceta Médica de México was of unquestionable importance for the National Academy of Medicine of Mexico, since it recorded the latest works, mostly related to diseases prevailing in Mexico, as well as medical news coming from abroad and topics on the life of the association. This publication interrelated the Academy with other associations, enabling for its position as a federal government advisory body to be expressed. As an essential journal for science and its dissemination, it was of vital importance for it to be released with full punctuality. However, the revolutionary movement that broke out in Mexico in 1910, followed by the struggle between factions, affected the Academy and hindered the continuity of the publication. The present study addresses the interruption suffered by Gaceta Médica de México in the years 1917, 1918 and 1919 first semester, as well as its resumption. In that context of internal struggles that plagued the country, it is worth answering some questions: How did the Academy manage to survive? What difficulties did it face? What events-led to Gaceta discontinuity? How was its resumption achieved?

\section{The association}

While it is true that the National Academy of Medicine, when it was still known as the Medical Sciences Section, emerged as a relevant association aimed at socializing medical knowledge, by the decade of the seventies of the $19^{\text {th }}$ century, it positioned itself as an epistemic association, since it became the Academy of Medicine, recognized by the Mexican government. That stable position of the corporation was reaffirmed in 1887, when it became the National Academy of Medicine, as its head officer, Dr. José María Bandêra, announced. ${ }^{1}$ That year, the Academy increased its working areas to 16: anatomy, physiology, physicsand chemistry, internal and external pathologies, surgical procedures, pharmacology, obstetrics, legal and statistical medicine, among others, which, as a whole, fostered scientific progress.
Correspondence:

*Martha Eugenia Rodríguez-Pérez

E-mail: martha.eugenia.rp@gmail.com

0016-3813/

license (http://creativecommons.org/licenses/by-nc-nd/4.0/).
Date of reception: 04-07-2019

Date of acceptance: 20-08-2019

www.gacetamedicademexico.com

Gac Med Mex. 2019;155:51ち515

Contents available at PubMed

BY-NC-ND 
On that ascending path, government recognition of the Academy culminated in 1912, when the President of the Republic, Francisco I. Madero, recognized the corporation as an official institution, since it was "advantageous for the government having a learned body to consult about scientific matters of its competence".

The Academy represented the most important medical group in nineteenth-century Mexico, which gathered on its account and committed itself to work under certain methodological standards. It brought together health specialists motivated by the study of national epidemiology, by the discussion of clinical cases, by the need to update advances of foreign medicine and by the debate with colleagues. All the knowledge that circulated within the medical community, in the Wednesday sessions, needed to be preserved, as pointed out by Dr. Miguel Francisco Jiménez, who held the presidency of the association in 1865, 1866, 1870 and 1872. Jiménez emphasized the importance of the Academy having a dissemination journal: Gaceta Médica de México came to light on September 15, 1864. It would allow, Jiménez used to express, to leave a record of the facts that were being experienced and the medical contributions to the benefit of contemporary and future generations of specialists. ${ }^{2}$

As the $19^{\text {th }}$ century progressed, the Academy grew in quantity and quality. For example, from 22 members in 1864, it went to 65 in 1878. On the other hand, at the conclusion of the $19^{\text {th }}$ century, its outgoing president, Doctor Luis E. Ruiz, claimed that the Academy worked silently but continuously and in the best possible way, in one of the most important phases of human well-being and perfectibility. Ruiz pointed out that the Academy worked with care for the most important of goods: health, and that "when it is lost, it works tirelessly to recover it, and if this is not achievable, to alleviate the sufferings and, in all cases, bring the balm of consolation to the spirits of all who suffer, which is always accomplished". ${ }^{3}$

The Academy concluded the nineteenth century working for national medicine through verbal communications, entertaining discussions, written reviews, reports, presentations of patients, instruments and devices, which together showed the state of medicine. By the end of that century, the predominant diseases were influenza, pulmonary tuberculosis, bronchitis, pneumonia and bronchopneumonia. ${ }^{4}$

The Academy initiated the $20^{\text {th }}$ century with great enthusiasm under the direction of Doctors José Ramón Icaza, José Terrés, Manuel Gutiérrez Zavala, Domingo Orvañanos, Nicolás Ramírez de Arellano,
Manuel Toussaint, Francisco Vázquez Gómez, Jưliân Villarreal, Ulises Valdés and Joaquín G. Cosío.

In 1914, 50 years after the founding of the Nationnal Academy of Medicine, a reflection on the ground Eovered and its achievements became necessary members joyfully recognized the progress of theinsociety thanks to the fact that, in words of Dr. Gregorio Mendizábal, full member of the Pharmacology and Pharmacy Section and subsequently honorary member, "no government had been hostile to it". That government support and the great teachers affiliated to the Academy since its founding in 1864 , contributed for medical practice and its science to be recogniżed in the nineteenth century as the best in America, and for that period being called by the beautiful title ofthe golden age of Medicine in Mexico". ${ }^{5}$ On that year, 1914, Dr. Mendizábal expressed that it was worth celebrating that the Academy continued to be acfive, given the political convulsions that were being experienced, referring to the civil war the country was going through since 1910, historically known as the Mexican Revolution, an armed struggle that Was fought between several demographic sectors and that generated political, economic and social instability to our nation.

\section{Gaceta interruption}

Gaceta Médica de México, the official dissemination body of the National Academy of Medicine, was uninterruptedly published from 1864 to 1916 , despite having a variable periodicity, most times fortnightly, but it was also published every ten days and monthly. Gaceta was a national pride because it allowed Mexico to be recognized by other cultured centers of the "Eivilized world". Its regularity was valued, since onlythis way the Academy members could submit their works in a timely manner to achieve an impact on werld medicine of those days.

Since 1910, instability in Mexico started with the Mexican Revolution, aimed at overthrowing the government of Porfirio Díaz. Violence worsened in 1913 with the "Ten Tragic Days", which ended with the "murders of Madero and Pino Suárez, president and vice president of Mexico, respectively. Regarding the country's academic life, and as an effect not only of the Mexican Revolution but also of World War II, since 1914, paper in Mexico began to be scarce, and that which arrived, was sold at high prices; Gaceta and many other periodicals were printed on importedpaper. Several medical journals were affected by this 
situation; for example, Boletín del Instituto Patológico delayed its issues, while the periodical La Escuela de Medicina was discontinued definitively with volume 29 in 1914.

In his report as outgoing president of the National Academy of Medicine, Dr. Joaquín G. Cosío expressed on October 1, 1915 that the corporation "has remained distant from politics, and for that reason, it has been able to continue its usual functioning, without the roars of the storm that have seeped through these walls having modified in the least the serenity and august calm of this scientific center that only cares for the well-being of man..." However, the political situation did affect the Academy. The clearest example occurred on March 10, 1915, when the weekly session was suspended for the first time in the life of the corporation, due to lack of a quorum, given that Emiliano Zapata's army had arrived to Mexico City. Another consequence of the warlike environment, perhaps the most noticeable, was the interruption of Gaceta Médica de México publication. Dr. Cosío expressed that "an unfortunate circumstance has affected us throughout the year, which is the failure to publish Gaceta Médica de Mexico, the journal of our Academy. We have abundant accumulated material, which we have been unable to bring to light, because the allocated resources that for thirty-six years we have received from different ministries responsible for education in our country have been lacking." The lack of funds, coupled with the extreme shortage and publication costs, forced the Gaceta editor, Dr. Everardo Landa, to quietly face the perspective of having to wait for greater support to his functions, once the political situation of the country was renewed. Although political difficulties continued, the Academy managed to publish the Gaceta volume corresponding to 1915 and, in time, volume XI of 1916, whereby the third series was concluded.

During the years of shortage, in fact, 1915 was known as "the year of starvation", the expenses for the survival of the Academy were directly paid by its members through voluntary fees; even some members of the board of directors reimbursed the Academy the bonuses they were entitled to. With the collected resources, the members, at least the full members, were able to continue their meetings amidst the warlike disturbances that occurred in Mexico City, since all of them encouraged the association, worshiped its work and promoted national medicine to the benefit of their homeland.

It should be mentioned that the corporation's expenses not only included the cost of the paper and

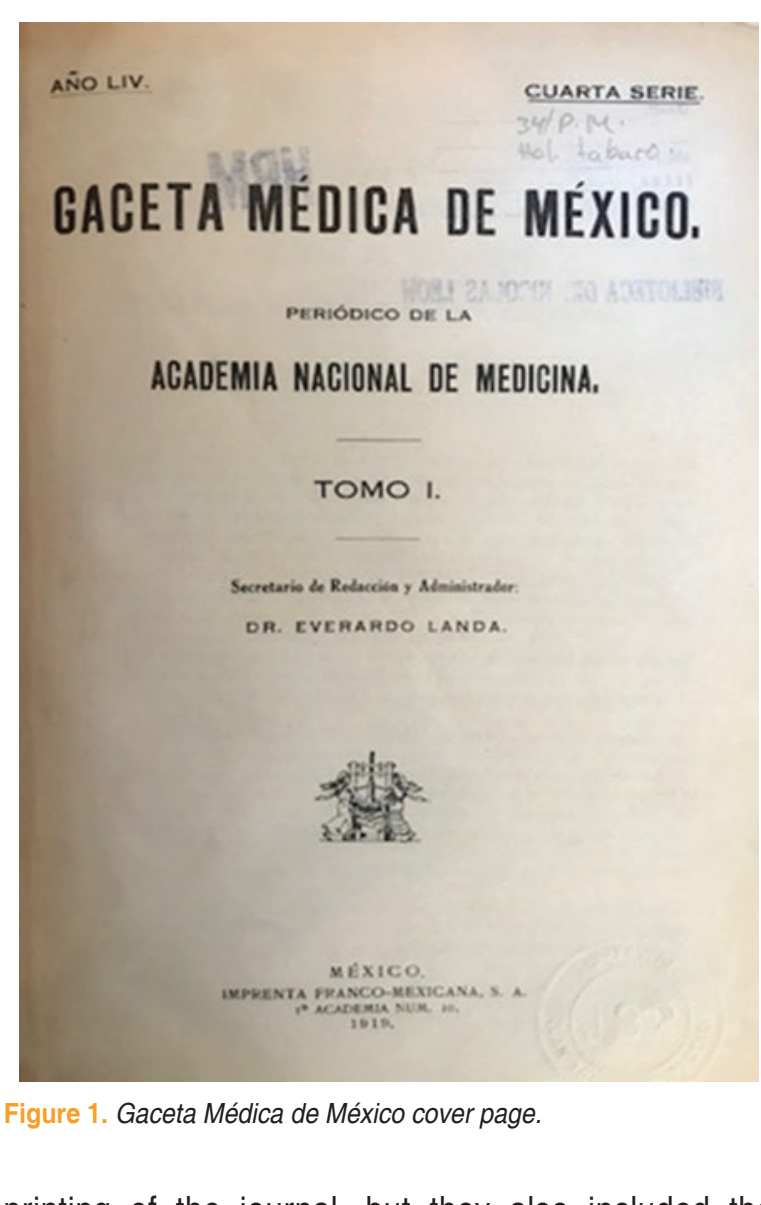

printing of the journal, but they also included the expenses of the corporation per se, payment to the employees, the treasurer, the clerk and the assistant, as well as the regulatory bonuses to academiciansfor on-duty works. All this increased debts and generated more. Therefore, given the critical environmentothe country was living in, Gaceta Médica de México was suspended during 1917, 1918 and first semestè of 1919.

\section{Gaceta resumption}

On July 1, 1919, Gaceta Médica de México was resumed and volume 1 of fourth series was published under the care of its editors, doctors Everardo Landa and Ángel Brioso Vasconcelos, who gathered dōcuments related to life of the Academy during the 19161919 period in a bulky issue. The next volume, under the care only of Dr. Vasconcelos, did not correspond to volume 2 , but to the $40^{\text {th }}$, because general numbering of published volumes was resumed. This last volume, also of irregular periodicity, corresponded tơthe years 1921-1925 (Fig. 1).

Retaking the publishing of Gaceta meant regulating activities at the Academy, a fact that was possible 


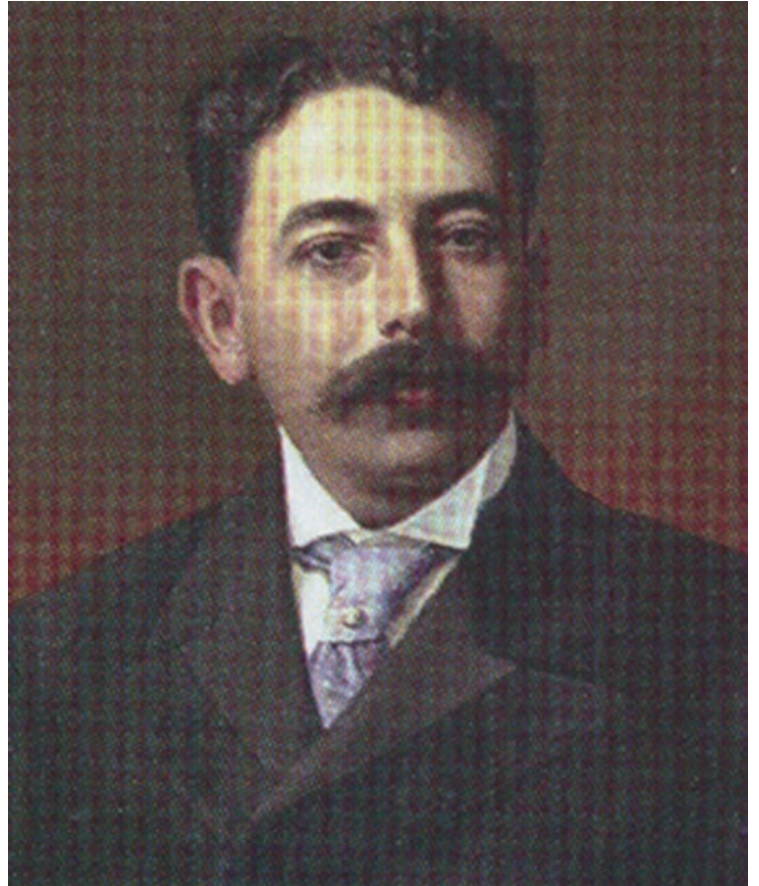

Figure 2. Dr. Emilio F. Montaño, president of the National Academy of Medicine (1919-1920), expressed the value of Gaceta Médica de México as a relevant means to learn about medical novelties.

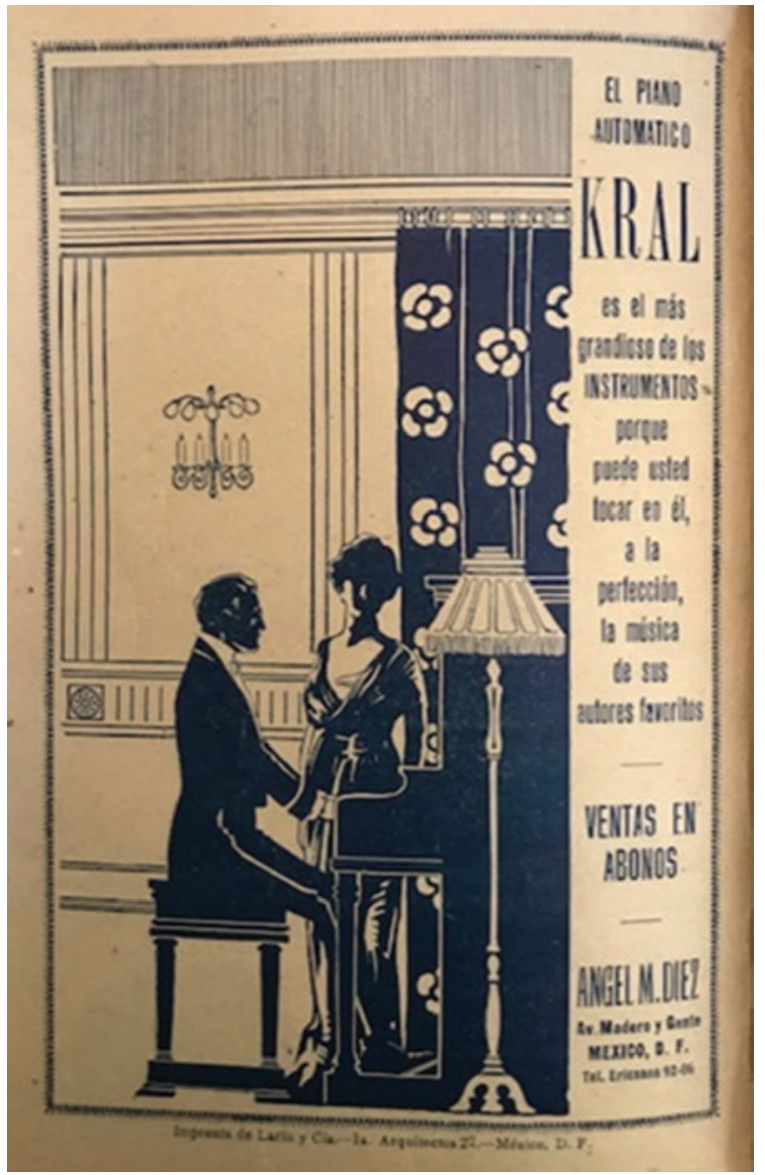

Figure 4. In 1921, Gaceta Médica de México inserted advertising in its pages.

\section{DoDge Brothers} EL AUTOMOVIL DEL DOOTOR.

Algunos de los médicos conocidos que usan nuestro automóvil:

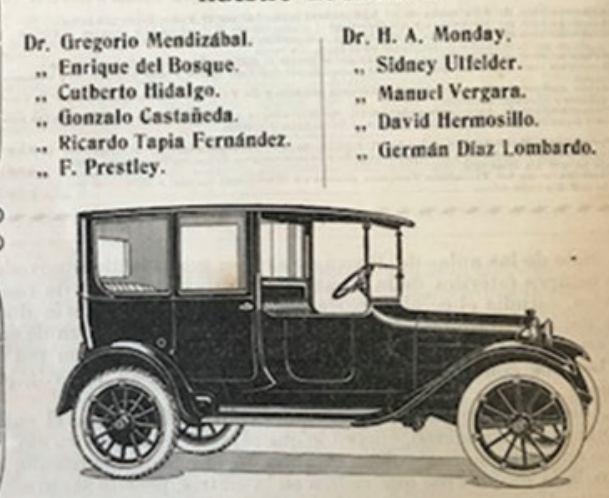

CIA. INIDA DE VEVIPSS, S. A.

Importaciones. Exportaciones

APARTADO 1220 AVENIDA JUAREZ, 84 MEXICO.

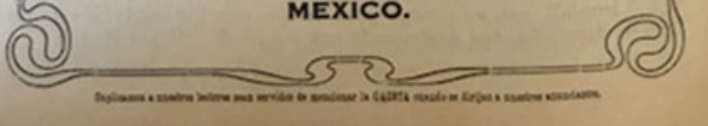

Figure 3. In 1921, Gaceta Médica de México advertised a bränd of automobiles to collect funds.

thanks to the support granted by various organizations: the Higher Council of Public Health, National School of Medicine, Bacteriological Institute and the political newspaper El Universal, as well as fees paid by private companies that advertised their products in Gaceta; Dr. Emilio F. Montaño, president of the Academy in the 1919-1920 period, said that they were still missing Rockefeller or Rothschild impersonators. Thus, with strong support, the National Academy of Medicine continued to serve the public at its offices and library, located in Brazil 33, from 07:00 to 21:00 hours.? Without a dissemination journal, the Academy functions were not complete, hence Dr. Montaño would express that "life of the Academy is linked to the "written works of its members, with the discussions that correct and complete these works and with their publication in its periodic journal: Gaceta Médica, which confers the corporation its teaching nature". ${ }^{8}$ Furthermore, Dr. Montaño stressed that the advances in science required new research procedures; patient bedside observation needed to be completed with laboratory testing and with foundations based on tocal 
or foreign experimentation, and reading through medical journals was therefore required. Thus, Gaceta Médica, Montaño used to say, needs to be a relatively expensive journal owing both to its materials and its presentation (Figures 2 to 4 ).

\section{Final considerations}

At 100 years of Gaceta Médica de México resumption, it is pertinent making a balance of the publication as the official journal of the National Academy of Medicine. Just as it emerged in 1864, due to the need to disseminate "science, and especially medicine", always working with "enthusiasm", the publication continued with the turn of the century until it stumbled into a forced interruption in 1916. The economic shortage of the hazardous revolutionary times reached academic life; however, with the efforts of academy members, printing again the publication that through its structure and contents showed to be the most prestigious medical periodical publication was possible. In 1919, when Gaceta publishing was resumed, the enthusiasm and commitment of the authors and-editors who compiled the retrieved materials resulting from the continuous academic sessions was noticed again, allowing the readers to pick up the guiding thread of the association: generation and dissemination of medical knowledge.

\section{References}

1. Fernández-Del Castillo F. Algunos datos históricos de la Academia Nacional de Medicina. En: Antología de escritos histórico médicos. México: Universidad Nacional Autónoma de México, Facultad de Medicina; 1978.

2. Jiménez MF. Sesión de clausura del año social 1866. Gac Med Mex. 1866;2:385-386.

3. Ruiz LE. Discurso de clausura del año económico 1898 a $18990 \mathrm{Gac}$ Med Mex. 1899;36:526-529.

4. Liceaga E. Algunos datos numéricos sobre la tuberculosis en México. Gac Med Mex. 1899;36:399-405.

5. Mendizábal G. Discurso leído por su autor con motivo de la celebrăción del $L$ aniversario de la fundación de la Academia Nacional de Medicina. Gac Med Mex. 1915;10:217-233.

6. Cosío JG. Discurso leído por el presidente de la Academia N. de Medicina en la sesión inaugural del día $1^{\circ}$ de octubre de 1915. Gac MedMex. 1915;1:550-556.

7. Soberón MR. Convocatoria. Gac Med Mex. 1920;1:1-2.

8. Montaño EF. Discurso del presidente saliente. Gac Med Mex. $1: 561-564$. 